Resona Jumal Ilmiah Pengabdian Masyarakat Vol. 2, No. 1 (2018) 12-17

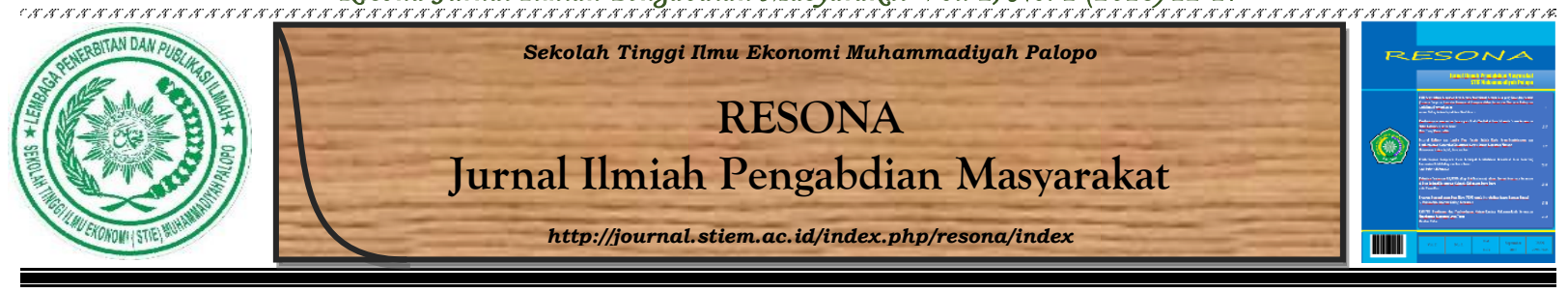

\title{
Pemberdayaan Masyarakat Pesisir pada Usaha Tambak di Desa Lakawali Pantai Kecamatan Malili Kabupaten Luwu Timur
}

Muh. Yusuf Qamaruddin

$\underline{\underline{\text { Sekolah Tinggi Ilmu Ekonomi Muhammadiyah Palopo }}}$

\section{INFO NASKAH}

Diserahkan

29 Desember 2017

Diterima

25 Juni 2018

Diterima dan Disetujui

7 Agustus 2018

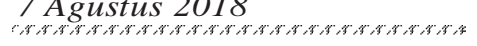

\section{Kata Kunci:}

Desa lakawali pantai

Masyarakat pesisir

Pemberdayaan

Usaha tambak

\begin{abstract}
ABSTRAK Program kegiatan Kuliah Kerja Nyata-Pembelajaran Pemberdayaan Masyarakat (KKN-PPM) di STIE Muhammadiyah Palopo merupakan program wajib bagi semua mahasiswa yang telah melulusi minimal 100 SKS. Hal ini dilakukan sebagai bentuk peran nyata kepada masyarakat dalam dharma pengabdian pada masyarakat. Tujuan yang akan dicapai dalam program KKN-PPM ini antara lain peningkatan kesejahteraan masyarakat pesisir melalui penyuluhan tentang perbaikan sistem pengelolaan lahan tambak yang baik dan ramah lingkungan. Target khusus yang ingin dicapai adalah tercapainya peningkatan income perkapita masyarakat melalui program pelatihan pembuatan pupuk organik untuk lahan tambak. Metode yang akan dipakai program kegiatan adalah: (a) melakukan pendataan awal terhadap kelompok sasaran pemberdayaan; (b) sosialisasi tentang program yang akan dilaksanakan melalui KKN-PPM kepada masyarakat petani tambak: (c) dan melakukan pelatihan pembuatan pupuk organik dan pendampingan dalam pengelolaan tambak yang dikerjasamakan dengan PPL setempat.
\end{abstract}

\section{Pendahuluan}

Desa Lakawali Pantai adalah salah satu desa di Kecamatan Malili yang dibentuk pada Tahun 2008 dari pemekaran Desa Lakawali, dimana sebagian besar penduduknya adalah mereka yang bekerja pada pertambakan. Ada sebagai pemilik tambak, penggarap bahkan hanya sebagai buruh tambak (sawi). Hasil pengamatan sementara ada dua persoalan atau masalah yang dihadapi masyarakat di Desa Lakawali, yaitu: (a) pengelolaan tambak tidak dilakukan secara baik sehingga tidak ramah lingkungan dan (b) penyakit yang sering terjadi pada bibit bandeng dan udang, sehingga mengurangi produksi yang pada akhirnya mengakibatkan kerugian pada petani tambak. 
Pemberdayaan secara konseptual pemberdayaan atau perberkuasaan (empowerment) berasal dari kata "power" (kekuasaan atau pemberdayaan) karena ide utama pemberdayaan bersentuhan dengan konsep mengenai kekuasaan sering kali dikaitkan dengan kemampuan kita membuat orang lain melakukan apa yang kita inginkan, terlepas dengan keinginan dan minat mereka. Ilmu sosial tradisional menekankan bahwa kekuasaan kaitannya dengan pengaruh dan kontrol (Suhartono, 2005:57).

Pemberdayaan adalah proses dan serangkaian kegiatan untuk memperkuat kekuasaan atau pemberdayaan kelompok lemah dalam masyarakat, termasuk individu-individu yang mengalami masalah kemiskinan sebagai tujuan, maka pemberdayaan menununjukan pada keadaan atau hasil yang ingin dicapai oleh sebuah perubahan sosial. Masyarakat yang berdaya, memiliki kekuasaan atau mempunyai pengetahuan dan kemampuan dalam memenuhi kebutuhan hidupnya baik yang bersifat fisik ekonomi, maupun sosial seperti memiliki kepercayaan diri, mampu menyampaikan aspirasi, mempunyai mata pencarian, berpartisipasi dalam kegiatan sosial, dan mandiri dalam melaksanakan tugas-tugas kehidupannya. (Hermanto, 2007).

Tambak sebagai sarana budidaya perairan, Hewan yang dibudidayakan adalah hewan air terutama ikan dan udang. Penyebutan tambak biasanya dihubungkan dengan air payau dan air laut, arti tambak sendiri merupakan kolam yang dibangun di daerah pasang surut yang dipergunakan sebagai tempat pembudidayaan ikan, udang, dan hewan lainnya yang hidup di air. Tambak juga merupakan genangan air dari campuran air laut dan air sungai yang dibatasi oleh pematang-pematang yang diatur dari pintu air untuk pembudidaya ikan dan udang.

Petani tambak adalah petani ikan/udang dimana orang tersebut memperoleh mata pencaharian pokok dengan melakukan kegiatan di bidang budidaya ikan di tambak yang dibedakan atas:

a. Pemilik tambak adalah mereka yang menguasai sejumlah tertentu tambak yang dikerjakan oleh orang lain dengan sistem bagi hasil.

b. Pemilik yang juga sebagai penggarap tambak adalah mereka yang tergolong sebagai petani penggarap dimana mereka memiliki sejumlah tambak yang dikerjakan sendiri dan di samping itu mengerjakan tambak orang lain dengan sistem bagi hasil.

c. Penggarap tambak adalah petani yang menggarap tambak orang lain tetapi tidak memiliki tambak sendiri dan memperoleh pendapatan dari hasil tambak yang mereka kerjakan setelah dikeluarkan biaya-biaya dalam satu musim panen. 
d. Sawi/buruh tambak adalah mereka yang sama sekali tidak memiliki tambak, mereka semata-mata bekerja untuk menerima upah.

\section{Masalah}

Identifikasi masalah terkait dengan keadaan yang ingin diperbaiki melalui program $\mathrm{KKN}$ PPM ini antara lain:

a. Bagaimana pemberdayaan masyarakat petani tambak di Desa Lakawali Pantai Kecamatan Malili Kabupaten Luwu Timur?

b. Apa faktor pendukung, penghambat, dan solusi pemberdayaan masyarakat petani tambak di Desa Lakawali Pantai Kecamatan Malili Kabupaten Luwu Timur?

Berdasarkan masalah yang dihadapi oleh masyarakat petani tambak Desa Lakawali Pantai tersebut, maka pengabdi tertarik untuk melakukan upaya-upaya yang dapat mengatasi masalah tersebut melalui program KKN-PPM yang kemudian melibatkan pihak-pihak terkait. Solusinya dengan diberikannya pupuk dan pakan alami oleh para petani menjadikan ikan-ikan cepat besar dan dibutuhkan pemahaman para petani dalam mengelolah tambak agar para petani tidak mengalami kerugian.

\section{Metode Pelaksanaan}

Metode pelaksanaan kegiatan yang ditawarkan untuk mengatasi permasalahan sekaligus menjadi solusi sebagai berikut:

\section{Persiapan dan Pembekalan}

Langkah awal dalam pelaksanaan program KKN-PPM dilakukan persiapan dan pembekalan dengan mekanisme sebagai berikut:

a. Mekanisme pelaksanaan kegiatan KKN-PPM

1. Melakukan pembekalan kepada mahasiswa dan Dosen Pendamping Lapangan (DPL);

2. Sosialisasi kepada masyarakat kelompok usaha sebagai sasaran kegiatan program KKNPPM; dan

3. Melakukan koordinasi dengan lembaga mitra untuk menyatukan persepsi dalam melakukan kegiatan KKN-PPM.

b. Materi persiapan dan pembekalan KKN-PPM

1. Penjelasan tentang program KKN-PPM; 
2. Peran dan tugas mahasiswa dan dosen pembimbing lapangan (DPL) dalam program KKN-PPM; dan

3. Penentuan kelompok sasaran kegiatan KKN-PPM berdasarkan usaha yang akan dikelola.

\section{Pelaksanaan}

Langkah-langkah dalam bentuk program yang akan dilaksanakan untuk mencapai hasil yang diharapkan dalam program KKN-PPM ini adalah sebagai berikut:

a. Sosialisasi tentang program yang akan dilaksanakan melalui KKN-PPM kepada masyarakat petani tambak:

b. Melakukan pelatihan pembuatan pupuk organik, cara mengatasi penyakit pada bibit/benur, dan pendampingan dalam pengelolaan tambak yang dikerjasamakan dengan PPL setempat; dan

c. Melakukan pendampingan usaha dalam hal proses produksi.

Langkah-langkah operasional yang diperlukan untuk mengatasi permasalahan antara lain:

a. Bersama dengan PPL, selalu memantau perkembangan usaha kelompok sasaran; dan

b. Melakukan koordinasi dengan instansi terkait, seperti Dinas Perikanan Kabupaten Luwu Timur untuk ikut membantu melaksanakan pembinaan usaha kepada kelompok sasaran.

\section{Hasil dan Pembahasan}

Pada rapat persiapan pelaksanaan, dibahas mengenai perencanaan, pelaksanaan, monitoring, dan evaluasi serta tindak lanjut program KKN-PPM. Waktu sosialisasi kepada masyarakat kelompok sasaran, penentuan dan penetapan kelompok sasaran kegiatan telah disepakati dalam rapat. Persiapan juga telah disepakati dalam rapat program-program KKNPPM yang akan dilaksanakan.

Program KKN-PPM ini dilaksanakan dengan melakukan kegiatan berupa melaksanakan pelatihan pengelolaan usaha tambak yang meliputi pembuatan pupuk organik, dan cara mengatasi penyakit pada bibit/benur, melakukan pendampingan usaha dalam hal proses produksi. Pelatihan ini dilakukan pada kelompok Tani Tambak.

Langkah awal dalam pelatihan adalah dengan melakukan penyuluhan kepada kelompok tani tambak dan bekerjasama dengan Penyuluh Pertanian Lapangan (PPL), yang dilakukan secara terpisah berdasarkan jadwal yang telah ditentukan sebelumnya. Setelah pelatihan 
dilakukan, maka diharapkan para anggota kelompok dapat mempraktekkan hasil pelatihan tersebut. Rencana tahapan berikutnya adalah pendampingan sampai masa panen dan pasca panen untuk menjamin keberlangsungan program KKN-PPM ini termasuk di dalamnya bagaimana memelihara sampai masa panen dan pasca panen, terutama untuk pemasaran hasil produksi, yang diperkirakan. Berikut foto dokumen tentang pembekalan dan rapat persiapan pelaksanaan program KKN-PPM.

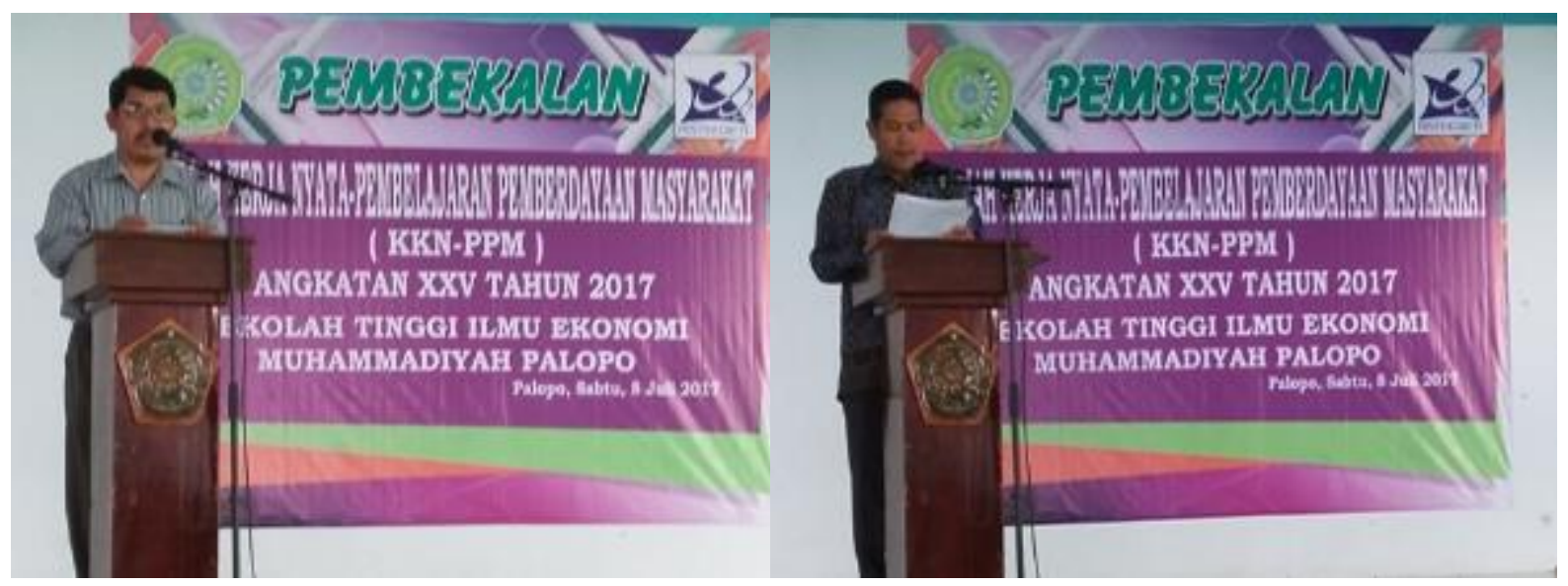

Gambar 1. Sambutan Ketua STIE Muhammadiyah Palopo dan Ketua P3M STIE Muhammadiyah Palopo

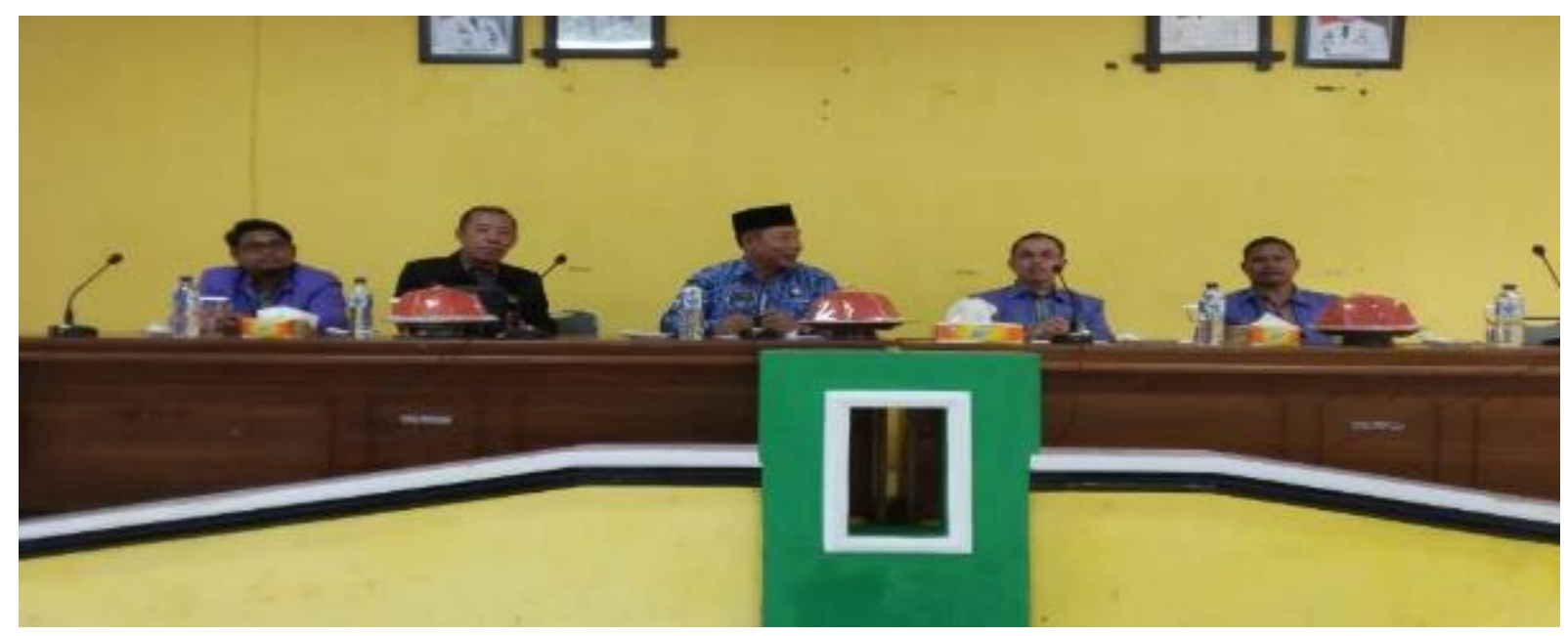

Gambar 2. Suasana Kantor Camat Malili saat Penerimaan Mahasiswa KKN-PPM 


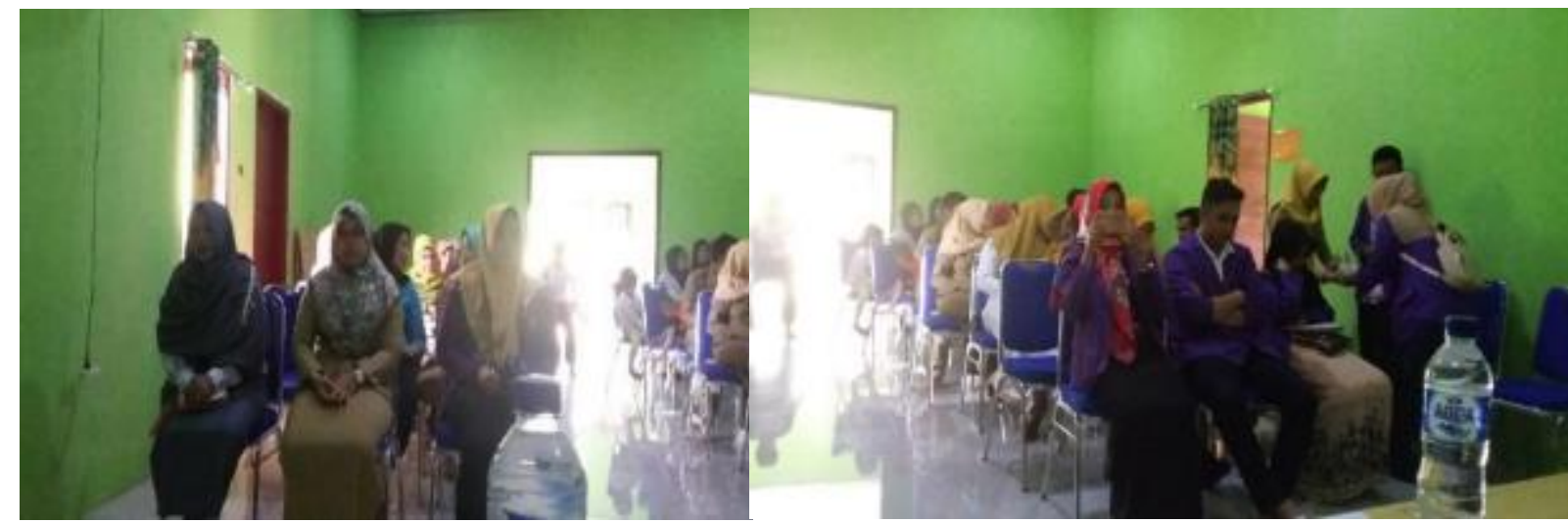

Gambar 3. Suasana Seminar Program Kerja Mahasiswa KKN-PPM

\section{Simpulan dan Saran}

Pelatihan dan pendampingan usaha yang dilakukan pada kelompok tani tambak di Desa Lakawali Pantai Kecamatan Malili Kabupaten Luwu Timur dapat meningkatkan pengetahuan dan keterampilan bagi anggota kelompok. Pelatihan dan pendampingan usaha dapat meningkatkan produksi, sehingga dapat meningkatkan pendapatan anggota kelompok.

Kelompok tani tambak yang sudah mendapatkan pelatihan dan pendampingan kiranya terus berusaha menambah pengetahuan dan keterampilan, sehingga usaha tambak yang ada dapat dikembangkan dapat berkelanjutan dan pada akhirnya dapat mensejahterakan anggota kelompok dan masyarakat sekitarnya.

\section{Daftar Pustaka}

Azizy, A.Q. 2004. Membangun Fondasi Ekonomi Ummat, Menoropong Prospek Berkembangnya Ekonomi Islam. Pustaka Pelajar. Yogyakarta.

Hermanto. 2007. Pengelolaan Budidaya Tambak Berwawasan Lingkungan. http://ikan mania.Wordpress.com

Suharto, E. 2009. Membangun Masyarakat Memberdayakan Masyarakat. Refika Aditama. Bandung. 